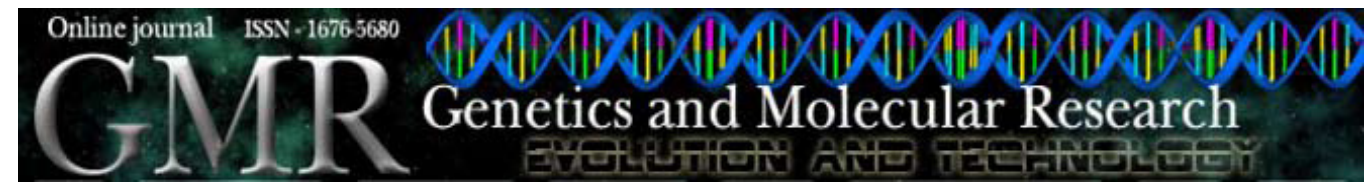

\title{
Evaluation of genetic variability in micropropagated propagules of ornamental pineapple [Ananas comosus var. bracteatus (Lindley) Coppens and Leal] using RAPD markers
}

\author{
M.D.M. Santos ${ }^{1}$, G.C.S. Buso ${ }^{2}$ and A.C. Torres ${ }^{3}$ \\ ${ }^{1}$ Departamento de Botânica, Universidade de Brasília, Brasília, DF, Brasil \\ ${ }^{2}$ Embrapa Recursos Genéticos e Biotecnologia, Brasília, DF, Brasil \\ ${ }^{3}$ Embrapa Hortaliças, Brasília, DF, Brasil \\ Corresponding author: A.C. Torres \\ E-mail: torres@cnph.embrapa.br
}

Genet. Mol. Res. 7 (4): 1097-1105 (2008)

Received July 21, 2008

Accepted August 5, 2008

Published October 21, 2008

\begin{abstract}
The objective of the present study was to evaluate the genetic variability in micropropagated plantlets of ornamental pineapple, after the fourth period of subculture. The basal culture medium consisted of MS salts, vitamins, $3 \%$ sucrose, liquid formulation, supplemented with 6-benzylaminopurine (BAP) at concentrations of $0.125,0.25,0.5,1.0$, and $2.0 \mathrm{mg} / \mathrm{L}$. The addition of BAP influenced the occurrence of genetic variation revealed using random amplified polymorphic DNA (RAPD) markers. Of a total of 520 primers tested, 44 were selected and amplified; 402 monomorphic bands (97.2\%) and 18 polymorphic bands (2.8\%) resulted among regenerated plantlets. The polymorphic fragments were produced by 12 primers (OPA-01, OPA-20, OPB-01, OPB-19, OPC-19, OPF-13, OPL-17, OPM-13, OPP-16, OPT-07, OPV-19, and OPX-03). Among the primers that identified polymorphism, OPA-01, OPA-20, OPB-19, OPC-19, OPL-17, OPP-16, and OPX-3 each showed, one polymorphic band and OPF-13 amplified a maximum of three bands. In this study, the RAPD technique was effective in showing the occurrence of
\end{abstract}


somaclonal variations that occur during the micropropagation process of ornamental pineapple cultivation in BAP-supplemented medium, and it is possible to detect the presence of genetic variation in early stages of plant development.

Key words: Ananas comosus var. bracteatus; Somaclonal variation; Genetic variation; In vitro culture; Mutation

\section{INTRODUCTION}

The ornamental pineapple (Ananas comosus var. bracteatus (Lindley) Coppens and Leal) is a monocotyledon plant from the Bromeliaceae family (Collins, 1960; Coppens and Leal, 2003) with great ornamental potential. The commercial propagation of this species is vegetative, using three types of propagules: crowns, suckers, and slips produced by the plant in the field. Each plant produces up to ten propagules per year, which limits its commercial cultivation (Correia et al., 2000). In addition, this kind of propagation may favor disease dissemination in the case of an unhealthy original plant. A strategy to avoid this limitation is to use in vitro culture for clonal propagation and fast growth of plants with important genotypes, theoretically, with the same genetic identity of the original material and with a high phytosanitary status. However, it has been observed that this technology may cause, in some situations, genetic modifications known as somaclonal variations (Larkin and Scowcroft, 1981) and also phenotypic modifications, called epigenetic variations (Evans and Bravo, 1986). These variations in micropropagated material, such as genetic and epigenetic modifications, need to be characterized. Genetic variations in plants from tissue culture have been cited in Lycopersicon esculentum Miller (Evans and Sharp, 1983), Nicotiana alata (Evans and Bravo, 1986), Ananas comosus (Das and Bhowmik, 1997; Gottardi et al., 2002; Feuser et al., 2003; Rodrigues et al., 2007), Musa sp (Martin et al., 2006) and Curcubita pepo (Leljak-Levanic et al., 2004), among others.

Recently, molecular markers have been utilized in the detection of variation or confirmation of genetic fidelity during micropropagation (Gupta et al., 1998; Tyagi et al., 2007). Among the polymerase chain reaction (PCR)-based markers frequently used, RAPD (random amplified polymorphic DNA) is considered to be efficient and cost effective. The technique only needs a few nanograms of DNA for a fast polymorphism analysis, does not require prior knowledge of DNA sequence, and does not involve radioactivity (Williams et al., 1990). RAPD markers have been employed to determine the clonal fidelity of micropropagated plants (Rani et al., 1995; Tang, 2001; Feuser, 2003). In the literature consulted, there is no knowledge about the genetic variability within and between plants derived from tissue culture of ornamental pineapple. The present study summarizes the application of RAPD markers to solve the problem mentioned.

\section{MATERIAL AND METHODS}

To evaluate genetic variability using RAPD, leaves were taken from in vitro cultures of Ananas comosus var. bracteatus. The cultures were established from axillary bud explants excised from the crown of one plant growing under field conditions. The starting medium was composed of MS salts (Murashige and Skoog, 1962), 3\% sucrose, 0.7\% agar and $100 \mathrm{mg} / \mathrm{L}$ myo-inositol, 0.1 $\mathrm{mg} / \mathrm{L}$ thiamine- $\mathrm{HCl}, 0.05 \mathrm{mg} / \mathrm{L}$ pyridoxine- $\mathrm{HCl}, 0.05 \mathrm{mg} / \mathrm{L}$ nicotinic acid, $2.0 \mathrm{mg} / \mathrm{L}$ glycine, 1.0 $\mathrm{mg} / \mathrm{L}$ 6-benzylaminopurine (BAP), $2.0 \mathrm{mg} / \mathrm{L}$ gibberellic acid $\left(\mathrm{GA}_{3}\right)$, and $0.01 \mathrm{mg} / \mathrm{L} \alpha$-naphthalene 
acetic acid. The cultures were illuminated $16 \mathrm{~h}$ per day with $32 \mu \mathrm{mol} \cdot \mathrm{m}^{-2} \cdot \mathrm{s}^{-1}$ irradiance provided by fluorescent light and exposed to a temperature of $27 \pm 2^{\circ} \mathrm{C}$ for 90 days. After this period, regenerated propagules of 1.5-2.0 cm in length were selected and added to flasks containing growth medium composed of MS salts, vitamins and 3\% sucrose, supplemented with $0.125,0.25,0.5,1.0$, and $2.0 \mathrm{mg} / \mathrm{L}$ $\mathrm{BAP}$, in liquid formulation. The $\mathrm{pH}$ of the medium was adjusted to $5.7 \pm 0.1$, before autoclaving. The cultures were incubated at $27^{\circ} \mathrm{C}$ with a $16-\mathrm{h}$ photoperiod with exposure to $32 \mu \mathrm{mol} . \mathrm{m}^{-2} . \mathrm{s}^{-1}$ irradiance. The propagules were subcultured monthly for 120 days. After the fourth subculture, 19 individuals for each BAP concentration were randomly selected for RAPD analysis, totaling 95 micropropagated propagules and one mother plant (control). The propagules were rooted and transferred to $3.0-\mathrm{cm}$ diameter tubes containing PlantMax substrate, until they were transferred to a greenhouse where they were kept for evaluation of possible morphological changes. Every micropropagated plant characterized in this study was derived from just one axillary bud excised from the mother plant. Initially, a screening using 520 Operon Technologies Inc. primers was performed. To select the primers, the mother plant DNA and two individuals from in vitro culture were used. The primers that showed polymorphic bands and/or amplified a larger number of robust and well-defined bands were selected and afterwards evaluated to determine which ones were more informative with respect to polymorphism.

\section{DNA extraction and RAPD analysis}

DNA was extracted from fresh in vitro leaves of regenerated plants and the mother plant, as described in Ferreira and Grattapaglia (1998). The DNA quantification and quality evaluation was verified on $1 \%$ agarose gels stained with ethidium bromide and visualized under ultraviolet light. The DNA amplification reactions were run by PCR. Each reaction mixture contained: $3.0 \mu \mathrm{L} 3.0 \mathrm{ng} / \mu \mathrm{L}$ genomic DNA, $4.92 \mu \mathrm{L}$ autoclaved Milli-Q water, $1.30 \mu \mathrm{L}$ 10X Taq DNA polymerase buffer, $1.04 \mu \mathrm{L}$ dNTPs at $2.5 \mathrm{mM}, 1.5 \mu \mathrm{L}$ primer (Operon Technologies, USA) at $10 \mathrm{ng} / \mu \mathrm{L}$ and $0.2 \mu \mathrm{L}$ Taq DNA polymerase enzyme, in a $13-\mu \mathrm{L}$ total reaction. PCR amplification was performed in an automated thermal cycler (Perkin Elmer) programmed for 40 cycles, each consisting of an initial denaturation of $1 \mathrm{~min}$ at $92^{\circ} \mathrm{C}$, followed by an annealing step of $1 \mathrm{~min}$ at $35^{\circ} \mathrm{C}$ and an extension step of $2 \mathrm{~min}$ at $72^{\circ} \mathrm{C}$, followed by a final extension step at $72^{\circ} \mathrm{C}$ for $7 \mathrm{~min}$. The amplified fragments were electrophoresed on $1.5 \%(\mathrm{w} / \mathrm{v})$ agarose gels in 1X TBE buffer, visualized by staining with ethidium bromide and photographed on ultraviolet light using the Eagleye ${ }^{\mathrm{TM}}$ system $\left(\right.$ Stratagene ${ }^{\mathbb{R}}$ ). The bands were identified visually by comparison to a 1-kb ladder (75 to 12,216 bp). The samples were scored based on presence or absence of the same size bands, where coding was 1 for presence on gel and 0 for absence. The entire analysis was repeated and only the reproducible bands were considered.

\section{RESULTS AND DISCUSSION}

Previously, a variety of experiments were conducted to select plant growth regulators to establish medium requirements for adventitious organ regeneration in ornamental pineapple tissue culture. BAP was effective for inducing in vitro shoot proliferation in this species (Santos, 2008). It seemed of interest to screen for the presence of somaclonal variation in regenerants obtained in medium supplemented with different BAP concentrations.

High-quality DNA was isolated from the ornamental pineapple leaves. Among the 520 RAPD OP-primers screened, 44 primers were selected based on the production of well-defined and scorable bands, which were used for fingerprint comparison between the 
mother plant and micropopagated propagules. The data in Table 1 show the primers, primer sequences, number of bands produced and total number of amplicons revealed by RAPD analysis of micropropagated plantlets.

\begin{tabular}{|c|c|c|c|}
\hline Primer & Sequence (5'-3') & Total number of bands & Polymorphic bands \\
\hline OPA-01 & CAG GCC CTT C & 12 & 1 \\
\hline OPA- 08 & GTG ACG TAG G & 12 & \\
\hline OPA-19 & CAA ACG TCG G & 11 & \\
\hline OPA-20 & GTT GCG ATC C & 7 & 1 \\
\hline OPB-01 & GTT TCG CTC C & 12 & 2 \\
\hline OPB-18 & CCA CAG CAG T & 10 & \\
\hline OPB-19 & ACC CCC GAA G & 9 & 1 \\
\hline OPC-19 & GTT GCC AGC C & 7 & 1 \\
\hline OPC-08 & TGG ACC GGT G & 8 & \\
\hline OPF-04 & GGT GAT CAG G & 7 & \\
\hline OPF-13 & GGC TGC AGA A & 14 & 3 \\
\hline OPG-19 & GTC AGG GCA A & 10 & \\
\hline OPI- 02 & GGA GGA GAG G & 15 & \\
\hline OPI-03 & AAG GCG GCA G & 9 & \\
\hline OPI-06 & AAG GCG GCA G & 10 & \\
\hline OPI-07 & CAG CGA CAA G & 12 & \\
\hline OPI-11 & ACA TGC CGT G & 10 & \\
\hline OPI-14 & TGA CGG CGG T & 8 & \\
\hline OPJ-13 & CCA CAC TAC C & 7 & \\
\hline OPK-17 & CCC AGC TGT G & 10 & \\
\hline OPL-08 & AGC AGG TGG A & 6 & \\
\hline OPL-17 & AGC CTG AGC C & 10 & 1 \\
\hline OPM-13 & GGT GGT CAA G & 12 & 2 \\
\hline OPN-16 & AAG CGA CCT G & 16 & \\
\hline OPO-07 & CAG CAC TGA C & 9 & \\
\hline OPO-10 & TCA GAG CGC C & 14 & \\
\hline OPP-16 & CCA AGC TGC C & 8 & 1 \\
\hline OPQ-05 & CCG CGT CTT G & 4 & \\
\hline POR-08 & CCC GTT GCC T & 6 & \\
\hline POR-09 & TGA GCA CGA G & 12 & \\
\hline OPR-10 & CCA TTC CCC A & 8 & \\
\hline OPR-14 & CAG GAT TCC C & 7 & \\
\hline OPR-16 & CTC TGC GCG T & 10 & \\
\hline OPR-17 & CCG TAC GTA G & 9 & \\
\hline OPS-04 & CAC CCC CTT G & 5 & \\
\hline OPT-07 & GGC AGG CTG T & 16 & 2 \\
\hline OPU-01 & ACG GAC GTC A & 12 & \\
\hline OPV-07 & GAA GCC AGC C & 7 & \\
\hline OPV-10 & GGA CCT GCT G & 8 & \\
\hline OPV-11 & CTC GAC AGA G & 5 & \\
\hline OPV-19 & GGG TGT GCA G & 12 & 2 \\
\hline OPX-03 & TGG CGC AGT G & 12 & 1 \\
\hline OPX-19 & TGG CAA GGC A & 12 & \\
\hline OPZ-08 & GGG TGG GTA A & 9 & \\
\hline
\end{tabular}

The 44 primers produced 420 well-defined fragments; among them, 402 bands were monomorphic (97.2\%) and 18 bands were polymorphic (2.8\%) (Table 2). A total of 40,320 fragments (number of propagules x number of bands obtained) were produced with an aver- 
age of 9.5 bands per primer. The length of the amplification products was between 298 and $5090 \mathrm{bp}$. The number of bands per primer varied from 4 (OPQ-05) to 16 (OPN-16 and OPT07) (Table 1). The polymorphic fragments were produced by 12 primers (OPA-01, OPA-20, OPB-01, OPB-19, OPC-19, OPF-13, OPL-17, OPM-13, OPP-16, OPT-07, OPV-19, and OPX03). Among the primers that identified polymorphisms, OPA-1, OPA-20, OPB-1 and OPB-20 produced one polymorphic band and OPF-13 amplified a maximum of 3 bands (Table 1). The polymorphism generated by OPC-19 was observed in 10 samples with genetic variation (38\%). Three variants were detected by the primer OPL-17; OPF-13, OPP-16, and OPT-7 were each able to identify two independent variants. OPA-20, OPA-1, OPB-1, OPB-19, OPN-13, OPV-19, OPX-3 independently identified one somaclonal variant (Table 3). Examples of RAPD profile of mother plant and micropropagated plantlets are shown in Figure 1.

\begin{tabular}{lc} 
Table 2. Summary of random amplified polymorphic DNA (RAPD) products from micropropagation propagules \\
and original plant of Ananas comosus var. bracteatus used in the present study. \\
\hline Description & RAPD \\
\hline Number of primers tested & 520 \\
Number of primers selected & 44 \\
Number of primers that showed polymorphisms & 12 \\
Total number of amplified bands & 420 \\
Total number of monomorphic amplicons & 402 \\
Total number of polymorphic amplicons & 18 \\
Percent of polymorphic bands & $2.8 \%$ \\
Size of amplified bands & $298-5090 \mathrm{bp}$ \\
Average number of polymorphic bands per primer & 1.5 \\
Average number of bands per primer & 9.5 \\
\hline
\end{tabular}

Table 3. Presence (+) or absence (-) of polymorphic RAPD bands generated by primers in Ananas comusus var. bracteatus propagules cultured in media with different 6-benzylaminopurine (BAP) concentrations, after 120 days.

\begin{tabular}{|c|c|c|c|c|c|c|c|c|c|c|c|c|c|c|c|c|c|c|c|c|c|c|c|c|c|}
\hline \multirow[t]{2}{*}{ Primer } & \multicolumn{25}{|c|}{ Polymorphic regenerants } \\
\hline & M & 5 & 7 & 15 & 16 & 26 & 27 & 28 & 38 & 39 & 50 & 51 & 52 & 53 & 54 & 58 & 63 & 64 & 66 & 74 & 75 & 78 & 86 & 93 & 95 \\
\hline OPA-01 & - & - & - & - & - & - & - & - & - & - & - & - & - & - & - & - & - & - & - & - & - & + & - & - & - \\
\hline OPA-20 & - & - & + & - & - & - & - & - & - & - & - & - & - & - & - & - & - & - & - & - & - & - & - & - & - \\
\hline OPB-01 & - & - & - & - & - & - & - & - & - & - & - & - & - & - & - & + & - & - & - & - & - & - & - & - & - \\
\hline OPB-01 & - & - & - & - & - & - & - & - & - & - & - & - & - & - & - & + & - & - & - & - & - & - & - & - & - \\
\hline OPB-19 & - & - & - & - & - & - & - & - & - & - & - & - & - & - & + & - & - & - & - & - & - & - & - & - & - \\
\hline OPC-19 & - & - & - & + & + & + & + & + & + & + & + & + & - & - & - & - & + & - & - & - & - & - & - & - & - \\
\hline OPF-13 & - & + & - & - & - & - & - & - & - & - & - & - & - & - & - & - & - & - & - & - & - & - & - & - & - \\
\hline OPF-13 & - & - & - & - & - & - & - & - & - & - & - & - & - & - & - & - & - & - & - & - & + & - & - & - & - \\
\hline OPF-13 & - & - & - & - & - & - & - & - & - & - & - & - & - & - & - & - & - & - & - & - & + & - & - & - & - \\
\hline OPL-17 & - & - & - & - & - & - & - & - & - & - & - & - & + & + & - & - & - & - & - & + & - & - & - & - & - \\
\hline OPM-13 & - & - & - & - & - & - & - & - & - & - & - & - & - & - & - & - & - & - & - & - & - & - & - & - & + \\
\hline OPM-13 & - & - & - & - & - & - & - & - & - & - & - & - & - & - & - & - & - & - & - & - & - & - & - & - & + \\
\hline OPP-16 & - & - & - & - & - & - & - & - & - & - & - & - & - & - & - & - & - & - & - & - & - & - & + & + & - \\
\hline OPT-07 & - & - & - & - & - & - & - & - & - & - & - & - & - & - & + & - & - & - & - & - & - & - & - & - & - \\
\hline OPT-07 & - & - & - & - & - & - & - & - & - & - & - & - & - & - & - & - & - & - & + & - & - & - & - & - & - \\
\hline OPV-19 & - & - & - & - & - & - & - & - & - & - & - & - & - & - & + & - & - & - & - & - & - & - & - & - & - \\
\hline OPV-19 & - & - & - & - & - & - & - & - & - & - & - & - & - & - & + & - & - & - & - & - & - & - & - & - & - \\
\hline OPX-03 & - & - & - & - & - & - & - & - & - & - & - & - & - & - & - & - & - & + & - & - & - & - & - & - & - \\
\hline
\end{tabular}

M: mother plant; propagules 5, 7, 15, and $16(0.125 \mathrm{mg} / \mathrm{L} \mathrm{BAP})$; propagules $26,27,28,38$, and 39 (0.25 mg/L BAP); propagules $50,51,52,53,54$, and $58(0.5 \mathrm{mg} / \mathrm{L} \mathrm{BAP})$; propagules $63,64,66,74$, and $75(1.0 \mathrm{mg} / \mathrm{L} \mathrm{BAP})$; propagules $78,86,93$, and 95 (2.0 $\mathrm{mg} / \mathrm{L} \mathrm{BAP})$. 


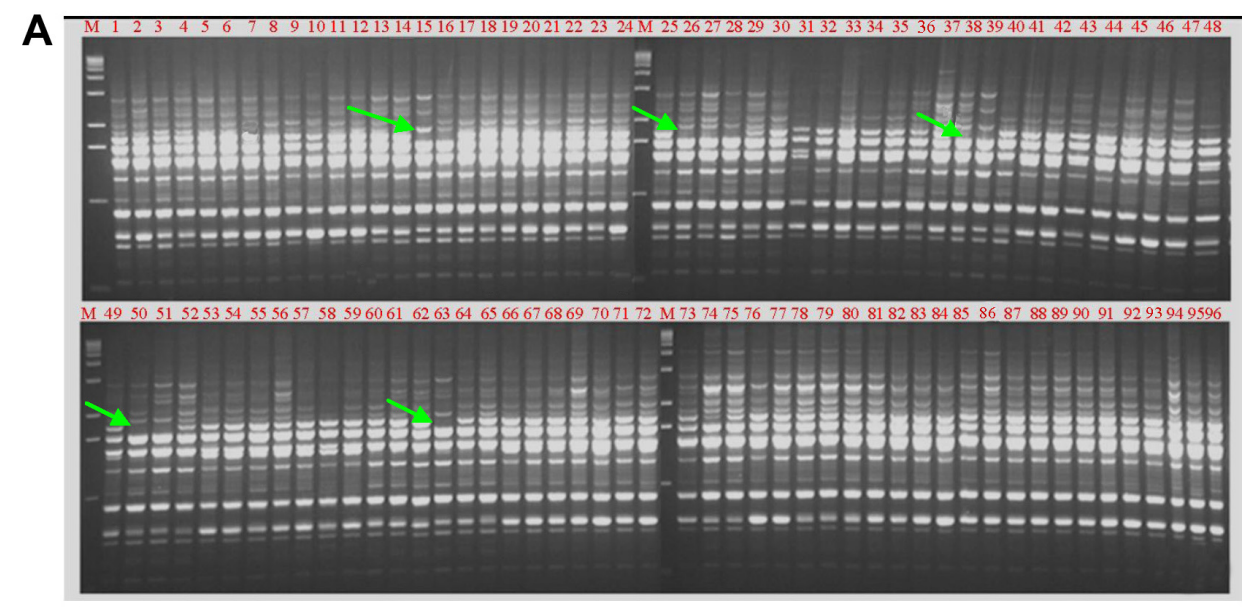

B

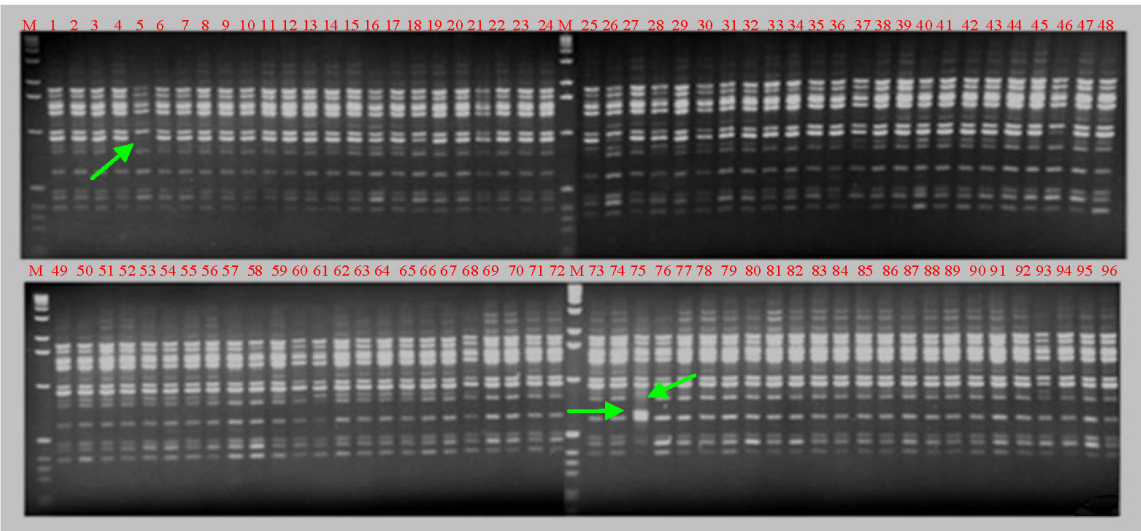

C

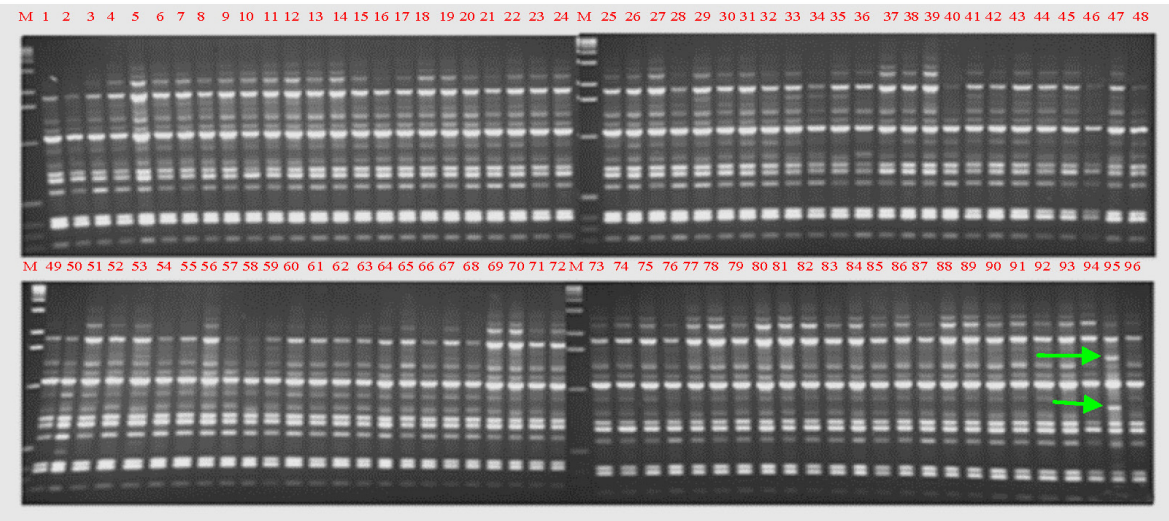

Figure 1. Molecular pattern of micropropagated plantlets revealed by RAPD on 1.5\% agarose gels, with the primers: A. OPC-19; B. OPF-13, and C. OPM-13. The arrows indicate polymorphic markers. The propagules were maintained in basal medium, liquid formulation, supplemented with BAP, subcultured every 30 days, for 120 days. $\mathrm{M}=$ mother plant. Lanes 1-96 = propagules regenerated in vitro in medium containing BAP. 
The percentage of polymorphism detected in Ananas comosus var. bracteatus in BAPcontaining medium was estimated to be 21 to $42 \%$, confirming the occurrence of variation during the micropropagation process. The variation of the electrophoretic pattern found in genomic DNA of regenerated propagules, after 120 days of culture, was probably due to the medium supplementation with BAP, according to a contingency test that showed a significant chi-square value (Table 4). This finding is consistent with those of Evans et al. (1984), Rani et al. (1995), Salvi et al. (2001), Feuser et al. (2003), and Costa and Zaffari (2005). In Ananas bracteatus cv. striatus, phenotypic variations of $52 \%$ albino plants and $20.5 \%$ green plants were described by Costa and Zaffari (2005). In commercial pineapple, Feuser et al. (2003) observed a more reduced rate of somaclonal variation among plantlets regenerated from in vitro culture using either stationary liquid medium or a temporal immersion system. These authors utilized 10 RAPD primers and detected 7.5 and $5.0 \%$ of somaclonal variants for the stationary and temporal immersion systems, respectively. However, in this latter study, the authors did not state the period of culture in which the samples were taken for RAPD analysis. The culture period directly influences the appearance of somaclonal variation (Skirvin et al., 1994), and the range of variation of 1 to $3 \%$ is expected in the process of micropropagation. Some authors have indicated that the treatment used in tissue culture, with high growth rate, may increase the variant numbers (Bairu et al., 2006). The regeneration systems from organized meristems, such as shoot tip and axillary buds, are considered to be the most efficient methods to guarantee genetic integrity of the micropropagated material. The regeneration methods from leave explants (Kawiak and Lojkowska, 2004) and callus (Skirvin et al., 1994) are considered to be less stable permitting the occurrence of genetic variation. In Drosera binata, plantlets regenerated through shoot tip preserve the genetic integrity of micropropagated plants. In Curcuma longa, rhizome bud explants used to establish cultures show genetic homogeneity in the regenerated propagules, when comparing them with the mother plant (Tyagi et al., 2007). However, plants regenerated from leaf base callus have shown variation at the DNA level during in vitro culture (Salvi et al., 2001; Tyagi et al., 2007).

Table 4. Chi-square values $\left(\chi^{2}\right)$ and probability $(\mathrm{P})$ of contingency test in the determination of genetic variability of propagules and original plant of Ananas comosus var. bracteatus as a result of the micropropagation process.

\begin{tabular}{lcccc}
\hline BAP concentration $(\mathrm{mg} / \mathrm{L})$ & Normal plants & Variant plants & $\chi^{2}$ & $\mathrm{P}$ \\
\hline 0.125 & 15 & 4 & 10.3 & $0.001-0.005$ \\
0.25 & 15 & 4 & 10.3 & $0.001-0.005$ \\
0.5 & 11 & 8 & 55.0 & $<0.001$ \\
1.0 & 14 & 5 & 18.1 & $<0.001$ \\
2.0 & 14 & 5 & 18.1 & $<0.001$ \\
\hline
\end{tabular}

The propagules were maintained in vitro in liquid medium supplemented with 6-benzylaminopurine (BAP), subcultured every 30 days and evaluated by RAPD after 120 days.

In this study, RAPD was effective in showing the variations that may occur as a result of mutations during the micropropagation process of Ananas comosus var. bracteatus in BAPsupplemented medium, and that could be useful in detecting the presence of genetic variation in the initial stages of plant development. Also, these findings could be applied in the breeding of this species. The regenerated plants are currently growing in a greenhouse, and later they will be transferred to the field and screened for morphological variation. 


\section{ACKNOWLEDGMENTS}

The authors are grateful to CNPq for the scholarships received.

\section{REFERENCES}

Bairu MW, Fennell CW and Van Staden J (2006). The effect of plant growth regulators on somaclonal variation in Cavendish banana (Musa AAA cv. 'Zelig'). Sci. Hortic. 109: 347-351.

Collins JL (1960). The Pineapple: Botany, Cultivation, and Utilization. Interscience Publishers Inc., Leonard Hill.

Coppens D'eeckenbrugge G and Leal F (2003). Morphology, Anatomy and Taxonomy. In: The Pineapple: Botany, Production and Uses (Bartholomew DP, Paull RE and Rohrbach KG, eds.). CAB International, New York, 13-32.

Correia D, Ribeiro KA, Rossetti AG and Silveira MRS (2000). Efeito do Ácido Indol Butírico e do Carvão Ativado no Enraizamento In Vitro de Brotos de Abacaxi Ornamental (Ananas lucidus Miller). EMBRAPA Agricultura Tropical, Fortaleza.

Costa F and Zaffari GT (2005). Micropropagação de Ananas bracteatus (Shultz) cv. striatus Hort. Rev. Bras. Hort. Ornamental 11: 109-113.

Das RK and Bhowmik G (1997). Some somaclonal variants in pineapple (Ananas comosus (L.) Merr.) plants obtained from different propagation techniques. Int. J. Trop. Agric. 15: 95-100.

Evans DA and Sharp WR (1983). Single gene mutations in tomato plants regenerated from tissue culture. Science 221: 949-951.

Evans DA and Bravo JE (1986). Phenotypic and Genotypic Stability of Tissue Cultured Plants. In: Current Plant Science and Biotechnology in Agriculture: Tissue Culture as a Plant Production System for Horticultural Plants (Zimmerman RH, Griesbach RJ, Hammerschlag FA and Lawson RH, eds.). Martinus Nijhoff Publishers, Dordrecht, 73-94.

Evans DA, Sharp WR and Medina Filho HP (1984). Somaclonal and gametaclonal variation. Am. J. Bot. 71: 759-774.

Ferreira ME and Grattapaglia D (1996). Introdução ao Uso de Marcadores Moleculares em Análises Genéticas. $3^{\text {a }}$ ed. Embrapa Cenargen, Brasília.

Feuser S, Meler K, Daquinta M, Guerra MP, et al. (2003). Genotypic fidelity of micropropagated pineapple (Ananas comosus) plantlets assessed by isozyme and RAPD markers. Plant Cell Tissue Organ Cult. 72: 221-227.

Gottardi MVC, Lemos EGM and Ruggiero C (2002). Avaliação por RAPD de plantas de abacaxizeiro cultivar Smooth Cayenne derivadas do seccionamento do talo e cultura de tecidos. Rev. Bras. Frutic. 24: 1-5.

Gupta PK, Singh SP, Balyan HS, Sharma PC, et al. (1998). Genetics and Biotechnology in Crop Improvement. Rastogi Publications, Meerut.

Kawiak A and Lojkowska E (2004). Application of RAPD in the determination of genetic fidelity in micropropagated Drosera plantlets. In Vitro Cell. Dev. Biol. Plant 40: 592-595.

Larkin PJ and Scowcroft WR (1981). Somaclonal variation - a novel source of variability from cell cultures for plant improvement. Theor. Appl. Genet. 60: 197-214.

Leljak-Levanic D, Bauer N, Mihaljevic S and Jelaska S (2004). Changes in DNA methylation during somatic embryogenesis in Cucurbita pepo L. Plant Cell Rep. 23: 120-127.

Martin KP, Pachathundikandi SK, Zhang CL, Slater A, et al. (2006). RAPD analysis of a variant of banana (Musa sp.) cv. grande naine and its propagation via shoot tip culture. In vitro Cell Dev. Biol. Plant 42: 188-192.

Murashige T and Skoog F (1962). A revised medium for rapid growth and bioassays with tobacco tissue cultures. Physiol. Plant. 15: 473-497.

Rani V, Parida A and Raina SN (1995). Random amplified polymorphic DNA (RAPD) markers for genetic analysis in micropropagated plants of Populus deltoides Marsh. Plant Cell Rep. 14: 459-462.

Rodrigues PHV, Dutra MFB, Faria OA and Lima AMLP (2007). Variação somaclonal em mudas micropropagadas de abacaxizeiro ornamental, Ananas bracteatus Schultes var. striatus (Bromeliaceae). Rev. Bras. Hort. Ornamental 12: $122-125$.

Salvi ND, George L and Eapen S (2001). Plant regeneration from leaf base callus of turmeric and random amplified polymorphic DNA analysis of regenerated plants. Plant Cell Tissue Organ Cult. 66: 113-119.

Santos MDM (2008). Micropropagação do abacaxizeiro ornamental [Ananas comosus var. bracteatus (Lindley) Coppens and Leal] e avaliação da fidelidade genotípica dos propágulos. Master's thesis, Departamento de Botânica, UNB, Brasília.

Skirvin RM, McPheeters KD and Norton M (1994). Sources and frequency of somaclonal variation. HortScience 29: $1232-1237$.

Tang W (2001). In vitro regeneration of loblolly pine and random amplified polymorphic DNA analyses of regenerated plantlets. Plant Cell Rep. 20: 163-168. 
Tyagi RK, Agrawal A, Mahalakshmi C, Hussain Z, et al. (2007). Low-cost media for in vitro conservation of turmeric (Curcuma longa L.) and genetic stability assessment using RAPD markers. In Vitro Cell Dev. Biol. Plant 43: 51-58.

Williams JG, Kubelik AR, Livak KJ, Rafalski JA, et al. (1990). DNA polymorphisms amplified by arbitrary primers are useful as genetic markers. Nucleic Acids Res. 18: 6531-6535. 